\title{
Modification of the conditioned emotional response in animals living in a $60-\mathrm{Hz}$ electrical field
}

\author{
ALLAN H. FREY and LEE S. WESLER \\ Randomline, Inc., Huntingdon Valley, Pennsylvania
}

\begin{abstract}
Frey and Spector (1976) suggested that the dopamine (DA) systems of the brain may be involved in the mediation of electromagnetic energy effects. It was hypothesized that a measure of emotionality that involves the DA systems, the conditioned emotional response (CER), would be modified by exposure of an animal to a $60-\mathrm{Hz}$ electrical field. This was tested with animals that lived in a $3.5-\mathrm{kV} / \mathrm{m}$ field. Significant differences appeared between exposed and shamexposed groups in leverpressing rates during the silent periods. During the 8 days of CER testing, the mean number of silent-period leverpresses for the exposed group was half that for the sham-exposed group. Significant differences were also found in the suppression ratio, with the exposed animals exhibiting increased suppression of response during the warning signal. Living in a $3.5-\mathrm{kV} / \mathrm{m} 60-\mathrm{Hz}$ electrical field appears to increase emotionality as defined by this test.
\end{abstract}

Frey and Spector (1976) suggested that the dopamine (DA) systems of the brain are involved in the mediation of electromagnetic-energy effects. Exposure to this energy has been found to affect avoidance, escape, timing, motor activity, and discriminative operant reward conditioning (Frey, 1965; Frey, 1971; Frey \& Feld, 1975; Gavalas, Walter, Hamer, \& Adey, 1970; Gillard, Servantie, Bertharion, Servantie, Obrenovitch, \& Perrin, 1976; Hjeresen \& Phillips, 1976; Medici \& Day, 1976; Mitchell, Switzer, \& Bronaugh, 1977; Monahan \& Henton, 1977). These types of behaviors have been found to have DA components (McGeer \& McGeer, 1980).

In one test of the hypothesis that the DA systems are involved in electromagnetic-energy effects, Frey and Spector (1976) found that exposure to microwavefrequency energy decreased aggressive behavior. Frey and Wesler (1979) found that tail-pressure behaviors, which involve the nigrostriatal DA system, were modified by exposure of the animal to the energy. In another test, Frey and Gendleman (1979) found that exposure of animals to microwaves degraded motor coordination or balance. Frey and Wesler (1983) reported that microwave-energy exposure antagonizes apomorphine's effects on the tail-flick test. This latter implies an influence of electromagnetic energy on presynaptic and postsynaptic DA receptors, and an interaction with the endorphin receptors. Frey and Wesler (1983) also reported that microwave energy alone could affect tail-flick sensitivity. Related to this is Stith and Erwin's (1980) finding that tyrosine hydroxylase activity in the hypothalamus and brain stem is significantly decreased by exposure of rats

The authors' mailing address is: Randomline, Inc., County Line and Mann Roads, Huntingdon Valley, PA 19006. to low-intensity microwave energy. They reported a significantly greater effect with pulsed energy than with continuous wave $(\mathrm{CW})$ energy of the same power level. DA is synthesized from tyrosine, and tyrosine hydroxylase acts on tyrosine in a rate-limiting step. They also reported a reversible decrease in DA in the hypothalamus and brain stem. Thus, evidence that the DA systems of the brain are involved as mediators in electromagneticenergy effects is accumulating.

Another prediction from the DA hypothesis is that mood and emotions, which involve the DA systems, would be modified by exposure of an animal to a $60-\mathrm{Hz}$ electrical field. The specific prediction was that a conditioned emotional response (CER), learned and tested outside the electrical field, would be affected in an animal living in an electrical field.

\section{METHOD}

The electrical-field exposure system consisted of a frame constructed of 2-in.-diam polyvinyl chloride (PVC) pipe. Racks made of aluminum channel, aluminum plates, and copper tubing were supported by horizontal 1 -in. PVC pipes that were attached to the PVC pipe frame. Half-inch stainless steel mesh assemblies served as cage floors that rested on the channel. Acrylic compartments with walls $3-\mathrm{mm}$ thick were attached to the mesh and formed the remainder of the cages, with individual compartments being $25 \mathrm{~cm}$ long $\times 11.5 \mathrm{~cm}$ wide $\times 10 \mathrm{~cm}$ high. Water was provided through the mesh floor through nipples mounted in PVC water pipes. Electrical measurement and the absence of weight differences between exposed and control groups in pilot tests indicated that the rats in the study received no perceptible microshocks while drinking in the home cage (Weijnen \& Mendelson, 1977). Also, all training and testing was done outside the field so that the watering system was not even involved in the CER procedure.

The horizontal surfaces of each rack assembly were $142 \mathrm{x}$ $81 \mathrm{~cm}$. The distance between horizontal surfaces was $43 \mathrm{~cm}$. 
Two rack assemblies, each consisting of three shelves of animals, were used; one rack assembly was energized, and the other was not. The experimenters did not know which rack assembly was energized. The walls of the room were lined with grounded 1 -in. mesh chicken wire. Grounded mesh was also used between the two rack assemblies. Calculations verified by measurements showed that the grounded mesh did not disturb the field. The field was generated by a transformer (Franceformer Model $3030 \mathrm{SMZ}$ ). The voltage to the transformer, and thus the field strength, was controlled by a variac. The line input to the variac, although stable, was conditioned by a Sola Model 23-22112-2 harmonic-filtered constant-voltage transformer.

The electrical field, between the cage floor and the plate above, was measured with a method and equipment developed by Misakian, Kotter, and Kahler (1978). The potential of the probe was matched to the ambient space potential with this equipment. Neither cage floor nor plate was connected to the probe or to the earth ground. The waveform was almost purely sinusoidal, as was verified by a spectrum analysis. A threedimensional field plot showed that the maximum variation in field strength between any two test points was $10 \%$. The maximum variation between adjacent test points was $6 \%$. The mean field strength was $3.5 \mathrm{kV} / \mathrm{m}$, with a standard deviation of $0.08 \mathrm{kV} / \mathrm{m}$. There was no measurable vibration, noise, or ozone from the exposure equipment (none would be expected at such low voltages, on the basis of Kaune's (personal communication) studies of $60-\mathrm{Hz}$ exposure systems).

Fourteen male Sprague-Dawley rats, weighing between 200 and $300 \mathrm{~g}$, were used. Water was freely available, but food was restricted to maintain the animals at $85 \%$ of normal body weight. The light/dark cycle was $12 \mathrm{~h}$. Half the animals lived in the $60-\mathrm{Hz}$ electrical field, and half lived in the same room but without field exposure. The experimenters did not know which group was exposed during the experiment. When training began, the subjects were housed individually in the room, and the field was turned on. Two series of tests were run, the first with one rack assembly energized, and the second with the other rack assembly energized. Different subjects were used in the two series.

The subjects were trained and tested outside the field and were returned to the field when the daily test was completed. They were out of the field $2 \mathrm{~h} /$ day. Tests were conducted in an acrylic box $9 \mathrm{~cm}$ wide $\times 15 \mathrm{~cm}$ long $\times 10 \mathrm{~cm}$ high. The floor of the test box consisted of a row of $0.64-\mathrm{cm}$-diam acrylic rods placed $1.3 \mathrm{~cm}$ apart, on centers. At one end of the box was a lever, which the animal pressed for food, and a food tray, which received $45-\mathrm{mg}$ Noyes pellets.

The subjects were placed on the food-deprivation schedule and were trained for 15 days, by the end of which they exhibited a stable response to a variable-interval $60 \pm 30$-sec schedule for $54-\mathrm{min}$ sessions. Then, alternating $7.5-\mathrm{min}$ periods of silence were followed by $1.5-\mathrm{min}$ periods during which a buzzer sounded. After 3 days of buzzer acclimation, a subject's tail was struck lightly by a solenoid plunger at the termination of each buzzer period to begin the CER test. Activation of a solenoid caused the plunger to lightly strike a $10-\mathrm{mm}^{2}$ area of the underside of the tail with a total force of $4 \mathrm{~N}$. On the basis of pilot studies, this aversive stimulus was set at the minimum necessary to obtain a CER. There were eight 54-min CER test sessions, one per day for 8 days. The subjects' leverpresses during the six silent and six buzzer periods throughout the 54-min sessions were recorded.

\section{RESULTS}

Data from the two series were combined. There were no significant differences in leverpressing behavior between the sham-exposed and exposed subjects during the training period. Once CER testing had begun, however, significant differences appeared between the leverpressing rates of exposed and sham-exposed groups during the silent periods. During the 8 days of CER testing, the mean number of silent-period leverpresses per day for the exposed group was 275 (SEM $= \pm 26$ ). For the sham-exposed group, the number was 602 (SEM = \pm 31 ). A two-way analysis of variance with data grouped for CER Days 1-3, 4-6, and 7-8 yielded a significant difference between sham-exposed and electrial-fieldexposed groups $(\mathrm{F}=16.02, \mathrm{p}<.005)$. There was also a significant difference over days $(\mathrm{F}=3.82, \mathrm{p}<.005)$ and a significant interaction $(\mathrm{F}=2.47, \mathrm{p}<.05)$ between days and treatment, indicating a change of the nature of the effect with repeated CER testing.

CER was measured as the suppression ratio (silentperiod response rate - buzzer-period response rate/ silent-period response rate) for each subject. A twoway analysis of variance showed a significant difference between electrical field-exposed and sham-exposed groups $(F=4.78, p<.05)$. There was also a significant difference over days $(F=8.71, p<.005)$ and a significant interaction $(F=4.76, p<.05)$ between days and treatment. The suppression means during CER testing are presented in Table 1.

Since there are excitatory and inhibitory DA receptors on neurons, and the exposed group data suggested a bimodal underlying population, the Moses test was run between the exposure and nonexposure conditions on the data gathered on Days 1-3 to better define the nature of the initial effect. The Moses test is specifically designed for use with data in which the experimental treatment affects some subjects one way and others in the opposite way (Moses, 1952). There was a significant difference between exposed and shamexposed groups $(p<.05)$.

\section{DISCUSSION}

Living in a $60-\mathrm{Hz}$ electrical field of $3.5 \mathrm{kV} / \mathrm{m}$ appears to increase emotionality as defined by significantly increased suppression of leverpressing response during both a warning sound period and quiet periods. Although the CER is frequently used as an animal analogue for anxiety, conclusions about human anxiety states should not be drawn from these results, because the CER is a complex behavior (Millenson \& Leslie, 1974). Furthermore, other interpretations, such as a heightened pain sensitivity, are possible. Apparently, the effect of an electrical field does not involve an influence on the learning of operant behavior, at least not until CER testing has started.

It is of special interest to note that individual animals living

Table 1

Suppression Means and SEMs during CER Testing

\begin{tabular}{cccccc} 
& \multicolumn{2}{c}{ Exposed } & & \multicolumn{2}{c}{ Sham-Exposed } \\
\cline { 2 - 3 } Days & Mean & SEM & & Mean & SEM \\
\hline $1-3$ & .05 & .07 & & -.07 & .02 \\
$4-6$ & .40 & .08 & & .12 & .04 \\
$7-8$ & .46 & .07 & & -.07 & .05 \\
\hline
\end{tabular}

Note-No suppression of leverpressing during the sounding of the buzzer would yield a mean of 0 or less, whereas total suppression during the buzzer period would yield a mean of 1 . 
in an electrical field fell into two distinct groups at the onset of the first CER test period. This is a phenomenon we have observed in several microwave-frequency-exposure experiments. It is consistent with the fact that numerous studies have shown that postsynaptic and presynaptic dopamine receptors have varying affinities for DA-related drugs based on dosage and receptor sensitivity (Hornykiewicz, 1977; Skirboll, Grace, \& Bunney, 1979). There may well be individual differences in receptor sensitivities to electromagnetic fields. This suggests that individual reactivities should be taken into account in electromagnetic-field experiments. Cools and van Rossum (1980) proposed that the balance of stimulation between $\mathrm{DA}_{e}$ and $\mathrm{DA}_{i}$ receptors is important in behavior regulation, and this may account for some of these results. Gnawing, for example, a behavior affected by electromagnetic-energy exposure (Frey \& Wesler, 1982) requires both increased $\mathrm{DA}_{\mathrm{e}}$ stimulation and decreased $\mathbf{D A}_{\mathbf{i}}$ stimulation, whereas sniffing needs either increased $\mathrm{DA}_{\mathrm{e}}$ or decreased $\mathrm{DA}_{\mathrm{i}}$ stimulation (Cools \& van Rossum, 1980). In this context, note that we used a minimal aversive stimulus. A strong aversive stimulus could be expected to involve other components of the behavioral system and could influence the response (Blackman, 1968).

The repeated finding that a test based upon multivariate hypergeometric distribution, the Moses test, is appropriate for use with some data from biological experiments with electromagnetic fields is of consequence. It implies that it would be useful to reconsider the validity of the conclusions of some earlier studies with electromagnetic fields. Real differences could have been obscured by the application of the more commonly used statistical tests that are based upon other distributions.

In sum, we have found that living in a $60-\mathrm{Hz}$ electrical field may influence emotionality in the rat, possibly through an influence on the DA receptors of the brain. Furthermore, the results indicate that use of the DA hypothesis for selecting neural and behavioral tests to determine the influence of exposure to $60-\mathrm{Hz}$ electrical fields is warranted. The results also have broad implications for the basic understanding of neural processes, because exposure to electromagnetic fields may provide a new tool for the study of such processes.

\section{REFERENCES}

Blackman, D. (1968). Conditioned suppression or facilitation as a function of the behavioural baseline. Journal of the Experimental Analysis of Behavior, 11, 53-61.

Cools, A. R., \& van Rossum, J. M. (1980). Multiple receptors for brain dopamine in behavior regulation: Concept of dopamine $_{\mathrm{e}}$ and dopamine $\mathrm{i}_{\mathrm{i}}$ receptors. Life Sciences, 27, 1237-1253.

Frey, A. H. (1965). Behavioral biophysics. Psychological Bulletin, 63, 322-337.

FreY, A. H. (1971). Biological function as influenced by lowpower modulated RF energy. IEEE Transactions on Microwave Theory and Techniques, MTT-19, 153-164.

Frey, A. H., \& Feld, S. (1975). Avoidance by rats of illumination with low power nonionizing electromagnetic energy. Journal of Comparative and Physiological Psychology, 89, 183-188.

Frey, A. H., \& Gendleman, S. (1979). Motor coordination or balance degradation during microwave energy exposure. Bulletin of the Psychonomic Society, 14, 442-444.

Frey, A. H., \& Spector, J. (1976, October). Irritability and aggression in mammals as affected by exposure to electromagnetic energy. Paper presented at the meeting of the International Union of Radio Science, Amherst, MA.
Frey, A. H., \& Wesler, L. S. (1979, July). Modification of tail pinch consummatory behavior by microwave energy exposure. Paper presented at the meeting of the International Union of Radio Science, Seattle, WA.

Frey, A. H., \& Wesler, L. S. (1982). A test of the dopamine hypothesis of microwave energy effects. Journal of Bioelectricity, 1, 305-312.

Frey, A. H., \& Wesler, L. S. (1983). Dopamine receptors and microwave energy exposure. Journal of Bioelectricity, 2, 145-157.

Gavalas, R. J., Walter, D. O., Hamer, J., \& Adey, W. R. (1970). Effect of low level low frequency electric fields on EEG and behavior of Macaca menestrina. Brain Research, 18, 491-501.

Gillard, J., Servantie, B., Bertharion, G., Servantie, A. M., Obrenovitch, J., \& Perrin, J. C. (1976). Study of the microwave induced perturbations of the behavior by the open field test into the white rat. In C. C. Johnson \& M. L. Shore (Eds.), Biological Effects of Electromagnetic Waves (Vol. 1, pp. 175-186) (HEW Publication No. FDA 77-8010). Washington, DC: U.S. Government Printing Office.

Hueresen, D. L., \& Phillips, R. D. (1976, October). Perception and response to pulsed microwave radiation by rats. Paper presented at the meeting of the International Union of Radio Science, Amherst, MA.

Hornykiewicz, O. (1977). Psychopharmacological implications of dopamine and dopamine antagonists: A critical evaluation of current evidence. Annual Review of Pharmacology and Toxicology, 17, 545-559.

McGeer, P. L., \& McGeer, E. G. (1980). Chemistry of mood and emotion. Annual Review of Psychology, 31, 273-307.

MEDICI, R., \& DAY, S. R. (1976). Effects of weak ELF electric fields on schedule controlled behavior in monkeys. In C. C. Johnson \& M. L. Shore (Eds.), Biological effects of electromagnetic waves (Vol. 1, pp. 215-225) (HEW Publication No. FDA 77-8010). Washington, DC: U.S. Government Printing Office.

Millenson, J. R., \& Leslie, J. (1974). The conditioned emotional response (CER) as a baseline for the study of anti-anxiety drugs. Neuropharmacology, 13, 1-9.

Misakian, M., Kotter, F. R., \& Kahle R, R. L. (1978). Miniature ELF electric field probe. Review of Scientific Instruments, 49, 933.

Mitchell, D. S., Switzer, W. G., \& Bronaugh, E. L. (1977). Hyperactivity and disruption of operant behavior in rats after multiple exposures to microwave radiation. Radio Science, 12 (6S), 263-271.

Monahan, J. C., \& Henton, W. W. (1977). Free operant avoidance and escape from microwave radiation. In D. G. Hazzard (Ed.), Symposium on Biological Effects and Measurement cf Radio Frequency/Microwaves (pp. 23-33) (HEW Publication No. FDA 77-8026). Washington, DC: U.S. Government Printing Office.

Moses, L. E. (1952). A two-sample test. Psychometrika, 17, 239-247.

Skirboll, L. R., Grace, A. A., \& Bunney, B. S. (1979). Dopamine auto- and postsynaptic receptors: Electrophysiological evidence for differential sensitivity to dopamine agonists. Science, 206, 80-82.

STith, R. D., \& ERwin, D. M. (1980). Effect of exposure to microwaves on the neuroendocrine status of the rat. Bioelectromagnetics Journal, 1, 236.

Weijnen, J., \& Mendelson, J. (1977). Drinking behavior. New York: Plenum Press.

(Manuscript received for publication April 2, 1984.) 